\title{
Israeli - Mauritanian Relations from 1999 to 2008
}

\author{
Mohamed M. Ali Abu Khadra ${ }^{1,2}$, \& Mohamed Mohamed Husein Mustafa ${ }^{1}$ \\ ${ }^{1}$ Faculty of Economy and Political Science, Cairo University, Cairo, Egypt \\ Correspondence: Mohamed A. Mohamed Abu Khadra, PhD Candidate in Faculty of Economy and Political \\ Science, Cairo University, Cairo, Egypt. E-mail: mohamedabukhadra49@gmail.com
}

Received: June 13, 2017

doi:10.5539/ass.v13n9p89
Accepted: July 19, $2017 \quad$ Online Published: August 25, 2017

URL: https://doi.org/10.5539/ass.v13n9p89

\begin{abstract}
The closer ties and relations between Mauritania and Israel had an effective impact on the Arab region, as the mutual interests between the two parties led to the creation of a sort of anxiety and turmoil in the relationship of Mauritania with the Arab countries, linked to them by the neighboring factor in addition to the history, culture, language and religion factors, where the Mauritanian-Israeli relations influence in several Arab and Islamic trends and to reach its maximum impact with respect to the Mauritanian relations for the war in Yemen, Iraq and the war in Syria and the Palestinian issue and the war on terrorism.
\end{abstract}

Keywords: International Relations, Mauritania And Israel, Mauritania Israeli Relations, Foreign Policy of Mauritania, Israel's Foreign Policy, the Arab Regional Security, National Security

\section{Summary}

Mauritanian-Israeli relations have witnessed remarkable development since the mid-nineties, particularly since the conclusion of the diplomatic agreement in 1995 and the military cooperation, strategy between the two countries, the subsequent military, economic agreements, mutual visits of high-level officials of the two sides, especially from the military people and the areas of these relations cover the cooperation in military intelligence, joint military projects in addition to the economic areas. As a result, the study aimed at the evolution stages of Mauritanian-Israeli relations and the impact of these relations on the Arab regional order and the Arab states and the study was divided into four chapters in addition to the introduction and conclusion, where the first chapter dealt with the determinants governing Israeli-Mauritanian relations, and the historical background on the origins of these relationships and the evolution stages and internal and external determinants governing the Israeli-Mauritanian relations. In the second chapter, we dealt with the content of the Mauritanian-Israeli relations, whether were the military relations and security issues or issues of economic relations and issues of political relations. According to the third and fourth chapter, they addressed determining the effect of this relationship on the current Arab situation and challenges, where its effect on actors in the Arab regional system and its impact on Arab national security was addressed. The study concluded that the Mauritanian-Israeli relationship remains strong partnership reaching the extent of the strategic alliance.

\section{Introduction}

The question of the order of relations in the Middle East has experienced many events and the links between the countries of the region have received a regional and international interest and among the most prominent of these relationships and links that recently appeared on the political scene is the Mauritanian-Israeli relations. Thus, the Mauritanian-Israeli relations have witnessed remarkable development since the mid-nineties of the twentieth century, during the rule of President Maaouya Ould Sid'Ahmed Al Taya, where the cities of New York, Madrid and Barcelona witnessed a series of secret communications between Mauritania and Israel on a high level, and in special circumstances and full confidentiality. Thus the first official ministerial contact between the former Mauritanian Foreign Minister Mohamed Salem OuldLakhal and Foreign Minister Shimon Peres has been conducted in 1995 in Madrid, under the auspices of the Spanish Foreign Minister Javier Solana and there was another meeting between the Mauritanian Minister Mohamed Salem OuldLaklah and former deputy Israeli Foreign Minister Yossi Beilin in Amman. Hence, this meeting is the second of its kind noting that this meeting has been attended by former Jordanian Foreign Minister Abdel Karim Al Kabariti, at the request of the Mauritanian minister, and it has already led to a formal agreement to open interest offices in both capitals (Tel Aviv and Nouakchott in 1995). 
It is noted that the Mauritanian-Israeli relations have been strengthened strongly by the variables occurring in the world and the region, which disclosed new data indicating the normalization of relations, and one of the most important variables is the American war on Iraq. Thus, in the light of the US strategy drawn for the Middle East, especially after the announcement on the American project of the Great Middle East.

Mauritania was not away any day from the course of what is happening of the developments at the level of the Arab - Israeli conflict. On the contrary Mauritania found itself in the heart of this conflict and the geographical relative distance from the Arab circle surrounding Israel was not a barrier against the emergence of mutual interests with Israel since the mid-nineties of the last century in spite of the early secret communications between it and Israel.

Many may think that Mauritania was in the back of basic scene and the movement of key actors both regions in the Middle East with respect to reactions of the Arab - Israeli conflict, but the fact is that it was at the heart of this conflict, moving to serve its national interests on one hand in consistent or not consistent with the overall context of the Arab policies followed.

Thus, the main question of the study is "what are the stages of Mauritanian-Israeli relations from 1999 to 2008 And how did Mauritania exploit its weakness in in the international relations?

We will address the subject of Mauritanian-Israeli relations through the following points: -

\section{Determinants of Mauritanian-Israeli Relations}

Foreign policy differs from state to another, as they reflect the orientations of the state which consists of the attitudes and perceptions and values dictated by historical experience and strategic conditions that characterize the state in the international politics which is rooted in tradition and the great ambitions of the communities. Thus, this makes the foreign policy of the State of Mauritania with a specificity that characterize Mauritania from the rest of the world as it is a weak state, located in the far Arab Maghreb on the Atlantic coast, and it is the big open gate on black continent of Africa, and the weakest security link between the Arab Maghreb countries, and the most Deserted and wild, the least controlled, and the most confusing geographical area. Thus, these data made Mauritania as the focus of bickering and the attention of many international powers, in addition to identifying an internal political context characterized by political instability and social heterogeneity, which has made the scholar of the Mauritania's foreign policy face a challenge regarding the influence of internal and external variables.

The geography is in the forefront of physical permanent factors of foreign policy and it is one of the most stable elements of the nation's policy and the most influential on its external behavior. Although this factor is now less important than it was before because of the technical development of the means of transport and communication and the wars. Thus, it still represents an essential significant factor on the foreign policies of all States (Morgenthau, 1965).

Moreover, the German leader, "Bismarck," says: "the geography is permanent element in politics", and it is a fact confirmed by others when they consider whether the states and individuals can change the history, they will not be able to modify geography (Boukntar, 1997).

\subsection{Internal Determinants Governing the Israeli-Mauritanian Relations:}

Internal environmental determinants are as follow:

\subsubsection{First, Geographical and Human Determinants:}

\subsubsection{Geographical Determinants:}

When we examine the geographical determinants, who in ancient times Napoleon Bonaparte proverb can be cited that said: "Geography played a big role," and is still till now and the political geography is integrated within this factor which means: employment of land to serve the policy. Thus, the natural location of state is important as it determines the country's foreign strategy and the state bordering the sea is different from the state that does not have the seacoasts, and the state that possesses water constraints and controls the marine entrances shall have certain strategies.

Thus, every location has its specificity and this specificity is imposing certain options not others. In addition, Mauritania is located in the far Maghreb on Atlantic Ocean coast, which runs with a length of $650 \mathrm{~km}$, thus forming its western border, and it is bordered to the north with Morocco and Western desert and the north-eastern with Algeria, on the east with Mali, and it is bordered to the south with Senegal. Thus, Mauritania is stretching on an area of $1085.805 \mathrm{~km} 2$, with a population of currently around 3.3 million people. 
Hence, Mauritania the big open gate on black continent of Africa, and the weakest security link between the Arab Maghreb countries, and the most Deserted and wild, the least controlled, and the most confusing geographical area. Thus, these data made Mauritania as the focus of bickering and the attention of many international powers.

\subsubsection{Human Determinants:}

As for the human determinant, it is a strength or weakness factor. Thus, in the case of Mauritania, it is a weakness factor, as it has a population estimated at 3.3 million people, in addition to the lack of social cohesion. Hence, the multiplicity of the population may give the largest activity for the foreign policy. Thus, when the internal capabilities are not sufficient to meet the needs, therefore the state resorts to building peaceful relations in the framework of economic blocs, and this may be a reason for breaking out external conflicts if it could not be done peacefully, in search of out of the crisis (Al-Laithi, 2003).

There are those who believe that the large number of the population is not a strength factor in the foreign policy; as China and India until recently did not affect much on the international level through their foreign policies, as well as the ethnic diversity within the state that has a major impact. Thus, this diversity may play a negative role by the formation of lobbies and pressure groups defending the interests of the identities to which they belong (Waldabno, 2006), (and this what is known by Mauritania as "between the Arab majority and Negro minority"), and the ethnic harmonious composition reflects positively on foreign policy and contribute to its compatibility.

\subsection{Second, Military and Economic Determinants}

\subsubsection{Economic Determinants}

Economics is a very important factor, and it gained this importance especially after the end of the Cold War as a result of the decline in the ideological and military factors. Thus, the factors of natural resources of oil and gas and other make the state exposed to the ambitions then the industrial production, agriculture, and the strength of the balance of trade, the volume of transactions, and the extent of the subordination of the state, and the strength of the currency's stability, the size of the entire indebtedness are very important factors in determining the nature of the foreign policy and its effectiveness.

\subsubsection{Military Determinants}

The military factor is very important and topped the interest in the Mauritanian foreign policy in the early stages of independence by searching for military support, and the conclusion of military cooperation accords with France to face the problems associated with the independence and the problem of borders with its neighbor, Mali, in 1963, the Moroccan ambitions in Mauritania, the desert war 1976 (Ould Ibrahim, 2007), and since the first military coup in 1978, which made everything under the control of the military, and the Mauritanian political life was militarized including the foreign decision (Al Wafi, 1995 ).

2.2.3 Investment of Mauritania's Weakness in International Politics through its Relationship with a Strong State or to be an Ally to a Strong State

The relationship between the strong state and the weak state is represented in the view of the strong state in the natural potential of mineral wealth and oil of the weak state in addition to geographical location that enables the strong state to access to a particular region through close cooperation with the weak state. Hence, the weak state considers the relationship with the State strong through security dilemmas. This explanation was presented by "Dr. Glenn Snyder," who is one of the most prominent specialists of international relations and one of the most prominent theoreticians in the alliance relationship between a strong party with a weak party in the alliance and he interpreted that as the weak state feels that it has just one of the two options either to fall into the trap as a result of strong state policies allied or that the weak state shall be affected by threats it is exposed to due to strong state abandonment in favor of understandings with the State opponent to the vulnerable state which threatens its security (Bin Huwaidin, 2014) .

In comparison between the Israeli powers and Mauritanian powers, it turns out that there is a clear difference for the elements of these powers between the two countries and this is reflected in the following tables:

Table 1. summarizes some of the basic characteristics of the Israeli and Mauritanian economies:

\begin{tabular}{lll}
\hline Statement & Mauritania & Israel \\
\hline population & 3537368 people for 2014 & 8180000 people in 2014 \\
the currency & Ounce (US dollar equals 355 ounces) & Shekel dollar is equal to 3.85 shekels \\
Per capita gross domestic & & \\
\hline
\end{tabular}




product To \$ 1275 per year US \$ 37206 per year

Source: the world bank 2016 - the table is prepared by the researcher published by the International Bank for Reconstruction and construction in 2016

Table illustrates the variation in the economic strength of each of Mauritania and Israel. Thus, we find that Mauritania has low-income while Israel is among countries where the individual gets a high income as a result of the rise in GDP.

* Ounce: Mauritania is the national currency exchange rate compared to the US dollar of $\$ 1=355$ ounce in 2014.

The source: the World Bank report, the price of the Mauritanian currency is determined according to the movement of a basket of currencies selected by Central Bank of Mauritania.

* Shekel: national currency exchange rate of Israel compared to the US dollar of $\$ 1=3.85$ shekels in 2014 .

Table 2. Summarizes the basic characteristics of the Mauritanian economy

\begin{tabular}{|c|c|c|c|c|c|}
\hline Area & Economy & $\begin{array}{l}\text { Natural } \\
\text { Resources }\end{array}$ & Agriculture & Industry & Trade \\
\hline $\begin{array}{l}1030070 \text { square } \\
\text { kilometers }\end{array}$ & $\begin{array}{l}\text {-Gross domestic product } \\
\text { is } \$ 2.8 \text { billion } \\
\text {-The annual growth rate } \\
\text { is } 1.9 \% \\
\text { Unemployment is } 23 \% \\
\text {-Revenue is \$ } 329 \\
\text { million }\end{array}$ & $\begin{array}{l}\text { - Petroleum } \\
\text { - Fish } \\
\text { - Iron Ore } \\
\text { - Gypsum } \\
\text { - Copper } \\
\text { - Phosphate }\end{array}$ & $\begin{array}{l}13 \% \\
\text { Of GDP } \\
\text { - Livestock } \\
\text {-Fish } \\
\text { sources } \\
\text { - Maize } \\
\text { - Wheat } \\
\text { - Dates }\end{array}$ & $\begin{array}{l}47 \% \text { of GDP } \\
\text { - Mining } \\
\text { - Fishing } \\
\text { - Services } \\
41 \% \text { of GDP }\end{array}$ & $\begin{array}{l}\text { Exports: } 1.4 \$ \\
\text { billion } \\
\text { Imports } \\
1.5 \text { \$billion }\end{array}$ \\
\hline
\end{tabular}

Source: Statistics of the Arab League for the year 2010

Table3. Summarizes the basic characteristics of the Israeli economy

\begin{tabular}{|c|c|c|c|c|c|}
\hline Area & Economy & $\begin{array}{l}\text { Natural } \\
\text { Resources }\end{array}$ & Agriculture & Industry & Trade \\
\hline \multirow{6}{*}{$\begin{array}{l}20,770 \\
\text { Square } \\
\text { kilometers }\end{array}$} & \multirow{2}{*}{$\begin{array}{l}\text { GDP } \\
\text { billion }\end{array}$} & \multirow{2}{*}{$\begin{array}{l}\text { petroleum } \\
\text { Gas }\end{array}$} & \multirow{2}{*}{$\begin{array}{l}\text { fruits } \\
\text { The flowers }\end{array}$} & \multirow{2}{*}{$\begin{array}{l}\text { High-tech } \\
\text { industries }\end{array}$} & \multirow{2}{*}{$\begin{array}{l}\text { Exports: } \$ 62 \text { billion for the } \\
\text { year } 2006\end{array}$} \\
\hline & & & & & \\
\hline & \multirow{4}{*}{$\begin{array}{l}\text { Unemployment } \\
\text { rate is } 6 \% \text { per } \\
\text { annum }\end{array}$} & \multirow{2}{*}{$\begin{array}{l}\text { Services } 25 \% \text { of } \\
\text { GDP } \\
\text { Industry } 10.2 \%\end{array}$} & \multirow{2}{*}{$\begin{array}{l}\text { The citrus } \\
\text { Dairy } \\
\text { products }\end{array}$} & \multirow{2}{*}{$\begin{array}{l}\text { Manufacture } \\
\text { of computers } \\
\text { and software }\end{array}$} & $\begin{array}{l}\text { Imports are } 61 \text { billion for the } \\
\text { year } 2006\end{array}$ \\
\hline & & & & & It is considered as a world \\
\hline & & Tourism: & Poultry & $\begin{array}{l}\text { Industry } \\
\text { contributes }\end{array}$ & $\begin{array}{l}\text { center for the manufacture } \\
\text { and production of diamonds }\end{array}$ \\
\hline & & & $\begin{array}{l}\text { Agriculture } \\
\text { contributes } \\
\text { to } 2.5 \% \text { of } \\
\text { GDP }\end{array}$ & $21.6 \%$ of GDP & $\begin{array}{l}\text { and it exported in the year } \\
2009 \text { equivalent amount of } \\
\$ 10 \text { billion and the trade } \\
\text { contribute by } 31.1 \% \text { of the } \\
\text { GDP. }\end{array}$ \\
\hline
\end{tabular}

Source: Statistics $2014 \mathrm{http} / \mathrm{data}$ world bank

Israel Wikipedia, the free encyclopedia http // arwikipedia

Israeli Foreign Ministry website in Arabic mfa.qor.il Israel

The table is prepared by the researcher. 


\section{The Evolution Stages of Mauritanian-Israeli Relations:}

To investigate the subject of these relationships, we should identify its roots and motives for both sides, and then trying to identify the following question: To where the normalization of relations between them arrived? What are the areas that have been normalized? Shall Mauritania be the starting point of the Israeli project in Africa and Asia? What is the Mauritanian position of these relationships (the people, the government, the opposition)? What are the future prospects for these relations after the decision to freeze and then cut these relations?

\subsection{First: Stage of Development of Mauritanian-Israeli Relations and its Motivations since the Mid-Nineties of} the Last Century

In the early nineties, Israel adopted a new policy whose practical and direct objectives were represented in reaching normal relations with the Arab world, and the turning point was driven by a range of considerations, the first consideration: Is the rise of the United States as the dominant power in the Middle East, and the second consideration is that the military balance of power became largely in favor of Israel, which enabled it to engage in the peace process (Ron Terra, 2010).

\subsubsection{Stage of Normalization}

The starting point of normalizing the Mauritanian-Israeli relations date back to the nineties of the twentieth century, the early returns, during the rule of President Maaouya Ould Sid' Ahmed Taya, who is the architect of this relationship, and there are those who point out that the Israeli interest in Mauritania dates back to the sixties of the twentieth century, as there were multiple individual communications in this regard with the Mauritanian official personalities, but they were met with an official Mauritania rejection and the Mauritanian passport remained bearing the words: "he is banned from the entry into Israel and South Africa," where the cities of New York, Madrid and Barcelona saw a series of secret communications between Mauritania and Israel at a high level and in a fully private and confidential conditions. Therefore, the first ministerial official liaison between the former Mauritanian Foreign Minister Mohamed Salem OuldLekhel with the Israeli Foreign Minister Shimon Peres in the June 18, 1995 in Madrid, under the auspices of the former Spanish Foreign Minister Javier Solana, and there was another meeting between the Mauritanian Minister Mohamed Salem OuldLekhel and former Israeli Deputy Foreign Minister Yossi Beilin in Amman. Thus, this meeting is the second of its kind noting that this meeting has been attended by former Jordanian Foreign Minister Abdel KarimKabariti, at the request of the Mauritanian minister (Al Madini, 2006).

One of its results was reaching a formal agreement to open interest offices in both capitals (Tel Aviv and Nouakchott) on November 27, 1995 (Al Khalafy, 1999). In line with the research methodology, this new development in the stages of relationships requires identifying the motives of the two parties to establish such a relationship.

\subsubsection{Mauritanian Motives}

Several - internal and external - factors contributed to motivating the Mauritanian political system to normalize its relations with Israel, and the most prominent of these factors are follow:

A - After Israel's participation in some NATO activities in the framework of cooperation under the Mediterranean Dialogue for NATO, Maghreb states - notably Mauritania - to sought provide support for the alliance, and to cooperate with it (Awad, 2007) because it considered it a the appropriate framework, which strongly contributes in its preservation and stability and protecting it from any potential security shocks, and believes it to get the security and provide it with the security and economic concessions by investing Israel's participation in this area.

B - The power of Mauritania sees that peaceful relations with Israel are the most successful way for developing a lasting peace in the Arab region. In this context, Rashid bin Saleh - Minister of Mauritanian media - says "The aim of the visit is to convince the Israelis of the peace process, and refraining from aggression against the Palestinian brothers. "

C- Mauritania's desire to ensure long-term stability in the Sahel and the Maghreb countries, and overcoming the challenges faced by these countries represented in the illegal immigration, drug trafficking, and border control (terrorist groups). This was reinforced in that the Mauritania has hosted many security and military meetings with the US side, and that the US has received the Mauritanian officers for this purpose.

D - Mauritanian authority's belief that the continuation of its relations with Israel will assist them in securing access to aid from the United States instead of France in the wake of a sharp disagreement with the latter, which provides aid to Mauritania (Al - Kurwy, 2011).

E- the feeling that Mauritania is being constantly threatened by Algeria, and Morocco, and this feeling was 
enhanced by the contribution of Algeria in the era of HouariBoumediene in the overthrow of mokhtar Ould Daddah, because of the support positions of Morocco in the Western Sahara issue, as well as an earlier position of Morocco that enhances this feeling that was refusing to establish the Mauritanian state as a Moroccan territory (Abu Zakaria, 2002).

F- The French authorities in June 1999, arrested a Mauritanian officer accused of torturing political prisoners, provoking the wrath of the Mauritanian leadership, and it has been represented in the expulsion of the French military experts from Mauritania, and the imposition of a visa on all French people wishing to enter its territory. On the other $\mathrm{h}$ was the Mauritanian reaction was represented in directing towards normalization of relations with Israel for gaining the Jewish lobby in the US administration to be a compensation for the French support in all its forms, at a time when Washington has put Mauritania on the blacklist in the cause of human rights and the practice of torture, and accused it of conducting reduction in the army that reached 500 military elements between 1987 and 1991.

\subsubsection{Israeli Motives}

Several combined factors have pushed Israel towards the normalization of relations with Mauritania can be summarized as follows:

A- The pursuit of Israel and the United States to establish a common security vision and security system in which the interests and stability of the Mediterranean countries in the West and South are overlapping collectively helping the Arab countries in the southern Mediterranean to absorb their neighbor the Israeli state, and thus becoming a permanent part of the Mediterranean security system (Al-Sahhaf, 2011).

(B) Attempting to integrate Israel in some NATO projects in the light of NATO's Mediterranean Dialogue for the normalization of military relationship the with the Arab countries, namely Jordan, Egypt, Morocco, Tunisia, Mauritania after the Oslo Accords failed to normalize Israeli - Arab relationship within this area, which is an approach achieved by the alliance on its behalf.

(C) the geographical importance enjoyed by Mauritania as a strategic location overlooking the Atlantic Ocean, and along the coast with a length of $650 \mathrm{~km}$, as well as the Sahara, which makes it a strategic partner in the exploitation of resources in this vast untapped space.

(D) An enormous mineral wealth in Mauritania, represented in iron, copper, and salt, and iron - which is spread in the form of mountain ranges - is the legendary wealth of Mauritania which is of high quality value exported mostly to European countries, particularly France, as well as the presence of fish wealth which is one of the most important pillars in Mauritania's economic activity, as Mauritania possesses the richest fishing areas due to the presence of different types of fish and aquatic organisms resulting from the warm ocean currents. Therefore, Israel has sought to invest as much as possible in order to strengthen its influence in the region, under the pretext of development of the economic projects, especially projects for fish farming.

(E) The Israelis believe that Mauritania pose a starting point towards the African continent. First, it has a vast area of land, and second, it is controlled by a relatively weak system of government, as well as on other factors that pave the way to make Mauritania a starting point for Israelis towards the African continent rather than being the Arab-Islamic cultural enlightenment center.

(F) Further deepening the split of the Arab ranks, and accelerating the process of normalization, and the illusion that all the Arab states - from the center to the parties - on the way to develop a closer relationship with Israel.

\subsubsection{Forms of Israeli - Mauritania Normalization}

Israeli - Mauritania normalization took several forms, and at different points of time as follows:

\subsubsection{Diplomatic Normalization:}

Mauritanian - Israel diplomatic normalization began in the October 28, 1999 in New York, when the establishment of diplomatic relations up to the ambassadors level of both countries was announced (Ould Ahmed, 2001). Thus, the former US Secretary of State Madeleine Albright contributed to the signing of the agreement, and she has stated after the signing, saying: "This agreement will result in good fruits for the Mauritanian people." In an interview with OuldMousa - a member of the Foreign Affairs Committee of the Mauritanian National Assembly - regarding the exaggeration of Israeli - Mauritania normalization, he replied: "No, on the contrary, this is not exaggerated, we opened an embassy in Israel, and they opened in an embassy in our country as was done by Jordan and Egypt. Thus, Mauritania has confidence through its relationship with Israel that there is only peace by exchanging relations between Arab countries and Israel and this will provide stability for the whole region, and that peace will only be implemented if the principle of dialogue was applied. " 
But the process of opening the two embassies had been preceded by visits by officials from both countries. Thus, at the end of October 1998, the Minister of Foreign Affairs of Mauritania in the government of Taya (Cheikh El AviaOuld Mohamed Khouna) visited Tel Aviv, to offer congratulations on the victory of Netanyahu of the Israeli government during which secret talks were held. Two weeks later, Ould Mohamed Khouna president of the Mauritanian government was appointed by President OuldTaya, which was considered as a reward for the outcome of his visit to Israel .

Thus, the visit OuldKhouna was met with popular and Arab rejection for being contradicted with the decisions of the League of Arab States on normalizing relations. In 2001, the Mauritanian Foreign Minister visited the territory of Israel, and met with Sharon. It indicates the strength of relations between the two countries that the Israeli ambassador in Nouakchott Ariel Karam held a ceremony of "the Israeli Independence Holiday" which is on the Palestinian Nakba - and it was attended by a number of Mauritanian officials and dignitaries (Ould-Abdallah, 2007).

As part of efforts to boost relations, Mauritania was visited by high-level delegation from the Israeli Knesset in the month of April 2000, headed by Naomi Chazan of the "Labour Party", and delegation included in its membership: Maxim Levy of Israel's mass, and Gideon Ezrah of Likud party, and HashemMahameed for the consolidated list Arabic party. Thus, the Israeli delegation was received by the Mauritanian President OuldTaya in the presidential palace and they held a dialogue on enhancing cooperation between the two countries and exchange of visits. one of the results of the meeting with the Mauritanian parliament was establishing a Parliamentary Mauritanian - Israeli Assembly to support peace. The visit was made in the amidst of tight security measures that were met with protest and condemnation by political and popular movements in Mauritania.

\subsubsection{The Security and Intelligence Normalization:}

Security and intelligence field also saw a close collaboration between the parties. Thus, sources in the Mauritanian leadership that it has obtained the Israeli security and intelligence expertise to help them stay in the hierarchy of power, especially after the collapse that hit the French - Mauritanian relations. This cooperation has been represented in the dismissal of some of Mauritanian officers from office by the Mauritanian leadership based on the advice given by the Intelligence Service of the Israeli foreign ministry to President Maaouya, at a time when the number of Israeli experts in Mauritania reached one hundred experts. Moreover, the security cooperation has seen remarkable development when Mauritanian approved the Israeli request containing Israeli nuclear waste burial in the Mauritanian desert in return for some financial aid (Al-Hariri,2003) and Israeli planes loaded with nuclear waste landed in Tidjikja Airport (Bamba,1999), despite denials by the Mauritanian leadership to grant its consent to store Israeli nuclear waste in Mauritania.

Moreover, this also includes the Mauritania approval for testing a long-range Israeli missile through its launch from Israel to infect targets in the Mauritanian desert and the subject of (nuclear waste) has been referred to the High Court in London, which issued a denial order, and confirmed the validity of the denial of the Mauritanian authorities. This level of normalization confirms Israeli penetration in the security Arab strategic fields in Africa, posing a threat to Arab national security

\subsubsection{Economic Normalization:}

The economic normalization was - and is still - a steadfast Israeli target in its strategy for "peace" with the Arab countries whose purpose is the abolition of the Arab boycott of Israel at all levels and the opening of the Arab markets, and the integration of Israel in the region, and to achieve its ambitions in the water and energy, as its economy suffers a clear scarcity in these two resources. Within this area, Israel has been able to exert very strenuous efforts to control the trade and economy of Mauritania, and subjecting it according to its directions and future perceptions, and in the way that serves their objectives in Mauritania on the one hand and the region in general on the other. The main steps taken in this area are as follows:

- The purchase of real estate in many different places of the Mauritanian cities, and contributing to building the country's largest hotels (Sabah Hotel), as well as the dairy plants (Chazzan, 2006).

- The introduction of Israeli goods to the market, and providing them to the Mauritanian consumer through French companies. The most important of these goods is "modem" devices manufactured by (R.A.D.) company Israeli, as well as the dates and Israeli clothing and medicines.

- Israel held many training courses in the Mauritanian banking sector in Israel, and providing scholarships. Moreover, two Mauritanian accountants have refused to go to Tel Aviv within this area (Awad, 2011). 


\subsubsection{Normalization in the Field of Communication:}

The communication sector saw - on the other hand - has seen a normalization of relations, represented in "Alfario 5" Franco-Israeli company by entering the Mauritanian market in telecommunications (wireless internet access), as the company itself was established as a French company in an attempt to mislead the people of Mauritania and the opposition forces that reject all forms of cooperation. The mentioned company participated in the forum organized by the Mauritanian government in pursuit of the latter to open communication field in front of other companies, and it is the first time that an Israeli company enters the Mauritanian market after it was in the previous time offering its products to the Mauritanian local markets via French companies.

"Company Wotroom" is implementing a project specializing in supplying Mauritanian internet service in cooperation with the Mauritanian Wimax Inc., where the company's general manager (Mohamed Ould Wade )says that : This technique is the result of a partnership between his foundation and Fario Israeli company, as the population in remote areas can benefit from the Internet and mobile phones without wires all the time.

Moreover, Mauritania has an Israeli company for mobile phones bearing the name of one of the clubs of Mauritania, a team "Mortell" Mauritanian football, which a joint Mauritanian - Israeli company established in the era of Maaouya Ould Sid' Ahmed Taya after the establishment of diplomatic relations. In addition, the mentioned sports team is one of the richest clubs of Mauritania, and it is an arm of the telecommunications company.

In light of the above, it can be said that: The normalization of Mauritanian - Israeli relations have come a long, and laid the foundations for economic mutual interests between the two parties, with the benefits of a big economic payoff that may be invisible to the people. Accordingly, it is not very easy to give up it, despite decision that has been taken to freeze relations by the Mauritanian government due to unforeseen reactions of the people at the level of the actors in the political, military, economic and security decision-making that can be raised by the invisible interest. Therefore, the decision to freeze relations - even though it was a political action is a difficult decision, because this level of relations in various fields reflects the depth of exchange and communication between Israel and Mauritania, as well as on Israel's aspiration to make Mauritania - over time the starting point for Israel to expand in Africa through various means and invisible through its vast territory (Bab,2008).

\section{The Stage of the Freezing Relations}

In light of the above data, we can say that Mauritania represents a special case in the subject of political normalization with Israel, as it is the only Arab state next to Morocco outside the frontline states, which established full diplomatic relations with it, which are the relations that exceeded the ceiling of the Arab government normalization and it also exceeded normalization in the context of the Maghreb. Thus, this relationship was - and is still - the subject of a strong conflict on the scene of Mauritania, whose the most prominent manifestations was the integration of the position of rejecting the normalization by the opposition forces in its confrontation with the government. Therefore, the decision to freeze - Mauritanian-Israeli relations taken by Mauritania in Doha emergency summit (Gaza summit) on January 16, 2009 represents apparently a response to the demands of the people of Mauritania and its solidarity with the Palestinian people against the backdrop of the Israeli attack on Gaza, while the decision to freeze holds other dimensions as follow:

(A) pre-emptive action taken by the ruling regime, in the framework of facing and tackling the political crisis of governance experienced by Mauritania from six months after it erupted, following the military coup in August 2, 2008, and the consequent internal and external challenges experienced by Mauritania as a result.

(B) Trying to get political gains, including gaining some legitimacy for the regime in Mauritania especially that the decision to freeze relations with Israel, was met with the support of all political parties and powers, including opposition parties to the ruling regime, which led the coup against President Ould Sid Sheikh Abdullah.

As a result of this new attitude, the momentum of the popular and political support to the President and the ruling Council of State increased and this was represented in the demonstrations of support organized by various political parties and powers following the announcement of the decision in the whole Mauritanian cities, including the capital, Nouakchott. Moreover, Mohamed Ould Abdel Aziz- President of the State Councildelivered a speech in front of hundreds of students from the University of Nouakchott, saying: "The ruling Council of State will always be close to the pulse of the national street, for which the Palestinian cause represents one of its concentrates" El Sayed,2009).

(C) An attempt to lift the isolation experienced by Mauritania in order to improve its international and regional relations, with the Arab countries in particular in an attempt to get the Arab and Islamic financial support to face 
the economic crisis it experiences. Perhaps talking about the offer of Libyan leader Muammar Gaddafi, the military to prepare a bill of the economic cost to cut off Mauritanian - Israeli relations represents an attempt to break the blockade imposed by the West on Mauritania after the military coup (Ould Aslam .

(D) Achieving the desire of the Mauritanian people and political parties in favor of the Palestinian cause on the media level, and in return, it enables to absorb the popular discontent worsening as a result of the continuation of this relationship bet over by the political parties and the parties opposing the governing council. Thus, the decision to freeze was as dropping one of the papers bet over by the forces opposing the coup. Thus, the Governing Council was able to recruit public support for the freezing decision to serve the tackling the congested political crisis through the activation of the call for meaningful dialogue with all political parties and powers in order to reach compromise solutions, and as an attempt to work on the dismantling of the front opposing the coup leaders in order to press them to participate in the political process, and rein the internationalization of the crisis, and getting out it with minimal losses.

(E) To emphasize that the foreign policy of Mauritania runs from the sovereign choice in the first place and from the higher interests of the Mauritanian people in the second place.

\section{Stage of Cutting off- Relations}

Mauritania experienced a sudden political developments after the decision to freeze diplomatic relations with Israel represented the demand submitted to the Israeli embassy staff to leave the capital, Nouakchott, more than a month after the announcement, and the closure of the embassy, and taking down the Israeli flag from above its building, and ending the work of surveillance cameras and security fortifications around the embassy. This was reinforced by another new political development in Mauritania represented in the victory of Mohamed Ould Abdel Aziz in the presidential elections held on July 18, 2009, to support its legitimacy in power, and enhances its status to the extent that he omitted reference to relations with Israel in his first speech in August 11 2009, as an elected president, saying only circular form in which he stressed that the achievement of peace in the world and in the Middle East in particular - requires the concerted efforts of the international system and bodies concerned (El sayed, 2009) .

This was followed by a sudden political development for Mauritania to attract the spotlight once again through its the sudden and rapid transformation to the development of (www.islamweb.net) its diplomatic relations with Iran, and the pursuit of the two sides to establish a strategic relationship under the disappointed Nouakchott governors from the Western positions that have remained rigid, despite direct normalization with Israel. It seems that Iran has used and invested the acrimony chance occurring between the Western powers and the political system in order to incorporate Mauritania to the anti-Western policies axis. Those relations were crowned by exchanging visits between the two official delegations at a high level, the latest of which is Mauritanian President Mohamed Ould Abdel Aziz's visit to Iran in late January 2010, and signing several military agreements and agreements in the areas of geological development and cooperation, and investment in the banking field, as well as funding for a program to solve the transportation problem in Mauritania, and the pledge that Mauritania shall support Iran in international forums, and to strengthen relations with it to the extent of the abolition of visas.

This sudden shift of the new political alliance has raised concern on three sides as follow:

A - the Kingdom of Morocco for being the first ally of President Ould Abdel Aziz in his coup on August 6, 2008, which severed ties with Iran in 2009, making it anxious due to the entry of Iran so strongly in its neighbor Mauritania.

B - Arab nationalist circles within Mauritania, which supported with Mohamed Ould Abdel Aziz, hoping to be the Savior of their non-Arabist tendencies of his predecessor.

C - Israel, as its concern raised the development of Mauritanian - Iranian relations, after it had been considered that its presence in the Mauritania is strategic.

In the midst of these political developments and its results, Ms. Al Naha duagterof HamdiOuld Meknes Mauritanian Foreign Minister announced at a mass rally organized by the majority parties in the capital Nouakchott on 22/3/2010 that her country cut off the diplomatic relations with Israel, and said:

"Let the world know from here that Mauritania has severed diplomatic relations with the State of Israel once and for all", and the Mauritanian political parties, including opposition parties welcomed the decision that they were demanding its implementation in the past. Moreover, the Mauritanian President Mohamed Ould Abdel Aziz also said during a meeting with Adnan Abu Al Hija, Palestinian ambassador in Nouakchott: "The Mauritania did not get any benefits from the relationship with Israel ... with an emphasis on his country's support for the Palestinian 
struggle to establish a Palestinian state with Jerusalem as its capital".

Mauritanian Foreign Minister stressed severing its relations completely at a symposium organized by the University of Nouakchott titled:

"issues with the national trend" .

7) Mauritania's relations with Israel through to the Arab Summit hosting No. 27:

Mauritania hosted the Arab summit in the No. 27 on 07/26/2016 after Morocco apologized its hosting and was scheduled to be held in 7-8 April / 2016 in the Moroccan city of Marrakech, after Moroccan Foreign Minister, "Salah Eddine Mezouar," apologized and told that the Secretary-General of the Arab League Mr. Nabil Al-Arabi thereof. Thus, the decision apologize for hosting the summit is based on the current circumstances in the region and the Arab-Arab differences. Despite the Arab anger directed at the Arab League and everything related to the Arab work, the events of the summit through the statements issued by the meetings of Arab leaders, are still weak and did not reach the level desired by the Arab peoples and Mauritania despite the weakness of its potential hosted the summit in spite of the difficult situation in this sisterly Arab country. However, at the same time, it alludes to an Arab country outside the map conflicts that hosted the summit, which means that it shall not be biased in discussing all the issues, in addition to that it might be a good ground to restore cohesion to the Arab-Arab relations, and this is what did not happen as the summit was attended by a small number of kings, presidents and emirs of Arab States while the Syrian seat under is still frozen .

The record of this summit included the following:

1) The summit record an unprecedented event which is represented in being held in a small and poor Arab country and its duration was one day.

2) The Secretary-General of the Arab League request to reform the Arab League for the Advancement of Arab positive role in the international arena and the service of peace and security.

3) The sympathy of the summit with the French initiative for the Middle East crisis which is the Arab-Israeli conflict and getting out of the stalemate that followed the Madrid Peace Conference .

\section{Conclusion}

Mauritania's foreign policy was characterized by multiple stages for relations with Israel and the Arab states. Thus, in the mid-nineties of the last century, the diplomatic relations between Mauritania and Israel began, and since 2009 freezing the relationship between the two countries began until the severance of diplomatic relations between the two countries in 2010. Since then, the Mauritanian leaders realized the importance of the role played by Mauritania in its foreign policy in the context of its knowledge circles which are is the Arab circle and African circle, Islamic circle and circle, and getting out of the state of weakness and retreat because of the establishment of diplomatic relations with Israel during the period from 1995 to 2010.

Those are following up the Mauritanian foreign policy, he shall finds that it has risen considerably since March 2009 after the closure of the Israeli embassy in Nouakchott. Hence the Mauritanian president "Mohamed Ould Abdel Aziz" expressed in an interview to Al-Ahram on August 1, 2016, the desire of Mauritania that Arab States shall regain their regional role assigned to them, and raising the problems facing the Arab countries and seeking to characterize and to search for solutions for them. In commenting on the question of how did the Arab countries confront the Israeli movements in Africa, called for these movements; because the Africa's interests with the Arabs are greater than the African interests with Israel. Moreover, he added that: Mauritania is now paying the price for cutting off ties with Israel by human rights groups after talking about those abuses was dimmed, and Mauritania faces big criticisms in this file, and said: We are ready to pay for the decision to sever our relations with Israel, and there was no justification for the existence of the Israeli embassy in Nouakchott.

\section{References}

Abu Zakaria, Y. (2002). Why Mauritania Chose Normalization? Al Bayan Journal. No. 182, 96-101.

Al - Kurwy, M. \& Abbas, F. A. (2011). Mauritanian - Israeli Relations from Normalization to Freeze to Suspension. Contemporary Arab Affairs, 4(1), 35-39.

Al Khalafy, M. (1999). Normalization Fever Sweeping the Maghreb Region. Retrieved from http://www.islamonline.net

Al Madini, T. (2006). The Arab Maghreb Union between the Survival and the postponement: A Historic Political Study. Damascus: publications of the Arab Writers Union.

Al Sahaf, M. M. (1981). This is Mauritania: A Study in the Geography of Modern Mauritania. Baghdad: Dar Al 
Rashid for Publishing.

Al Wafi, A. (1995). Tribal Authority and Systems Central of the State in Mauritanian Society. Al Mustqbel Al Arabi Journal, 198, 84-88.

Al-Hariri, J. (2003), Mauritania and the Internal Tensions, International Papers. Center for International Studies, University of Baghdad. No. 122, 7-8.

Al-Laithi, H. (2003). The policies of fighting against poverty and gender-based inequality in the Arab region, for human development report in the Arab world and a range of statistics and social indicators for the ESCWA countries . Retrieved from http://www.unic.un.org.pl/hdr/hdr2003/hdr03_complete.pdf

Aslam, M. O. (2009) Mauritania: Position in the auction. Arab News, January 19. Retrieved from http://www.alarabiya.net/views/2009/01/19/6451O.html

Awad, M., Salem, M., \& Obaid, A. (2007). Resisting Normalization: Thirty years of confrontation. Beirut: Center for Arab Unity Studies.

Bab, O. S. (2008). Manifestations of Political Participation in Mauritania. Beirut: Institute for Arab Unity Studies.

Bin Huwaidin, M. (2014). The Dilemma of US-Gulf Relations. Al Bayan Newspaper, 11/05.

Boukntar, H. (1997). Arab policy of the Kingdom of Morocco, Strategic Research. Rabat: Center of the Arab-European Studies.

Dada, A. O. etc... (2002). Army, politics and power in the Arab world Beirut. Center for Arab Unity Studies.

El sayed, A. (2009). Ould Abdel Aziz leads Mauritania to a new stage. Al Quds Al Arabi. 13/8/2009.

Farouk, A. Mauritania, Escalation between the Government and the Islamists. Retrieved from http://www.annoormagazine.com

Ibrahim, M. A. O. (2007). Mauritanian Foreign Policy. Nouakchott: Mauritania's Center for Development Research.

Morgenthau, H. (1965). Politics among Nations: The Struggle for the power and Peace (Translated by Khayri Hammad). Cairo:Nationa House for Printing Press

Terra, R. (2010). Israeli reports for all publications of the Israeli Institute for National Security Studies (p. 20). Cairo: Arab Center for the Humanities.

The Islamic Republic of Mauritania. Retrived from https://en.wikipedia.org/wiki/Mauritania

Waldabno, B. (2006). Political and Civil Renewal in Mauritania: Did You Endure Conditions. Mauritanian people's Newspaper, April 17, p 2.

Walid, F. (2005). Normalization with Israel, An Essential Link in the Imperial Designs in the Region. Retrieved from Al Monadel Site http://almounadil-a.info/article241.html

\section{Copyrights}

Copyright for this article is retained by the author(s), with first publication rights granted to the journal.

This is an open-access article distributed under the terms and conditions of the Creative Commons Attribution license (http://creativecommons.org/licenses/by/4.0/). 